IRA-International Journal of Education \& Multidisciplinary Studies

ISSN 2455-2526; Vol.13, Issue 02 (November, 2018)

Pg. no. 13-18.

Institute of Research Advances

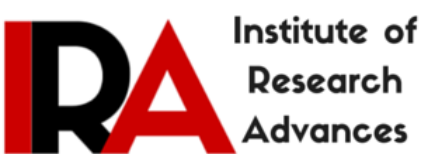

http://research-advances.org/index.php/IJEMS

\title{
Gender, Education and Post-traumatic Reactions of Victims of Cattle Rustling in Zamfara State, Nigeria
}

\author{
Gidado Likko, LAWAL ${ }^{1}$, Akilu Isma'il ${ }^{2 \#}$ and Amina Rahma Audu ${ }^{3}$ \\ ${ }^{1,3}$ Department of Educational Foundations, Federal University Gusau, Zamfara State, Nigeria. \\ ${ }^{2}$ Department of Science Education, Federal University Gusau, Zamfara State, Nigeria.
}

corresponding author.

Type of Review: Peer Reviewed.

DOl: http://dx.doi.org.10.21013.jems.v13.n2.p2

\section{How to cite this paper:}

LAWAL, G.L., Isma'il, A., Audu, A.R. (2018). Gender, Education and Post-traumatic Reactions of Victims of Cattle Rustling in Zamfara State, Nigeria. IRA International Journal of Education and Multidisciplinary Studies (ISSN 2455-2526), 13(2), 13-18.doi: http://dx.doi.org.10.21013.jems.v13.n2.p2

(C) Institute of Research Advances.

.This work is licensed under a Creative Commons Attribution-Non Commercial 4.0 International License subject to proper citation to the publication source of the work.

Disclaimer: The scholarly papers as reviewed and published by the Institute of Research Advances (IRA) are the views and opinions of their respective authors and are not the views or opinions of the IRA. The IRA disclaims of any harm or loss caused due to the published content to any party.

Institute of Research Advances is an institutional publisher member of Publishers Inter Linking Association Inc. (PILA-CrossRef), USA. The institute is an institutional signatory to the Budapest Open Access Initiative, Hungary advocating the open access of scientific and scholarly knowledge. The Institute is a registered content provider under Open Access Initiative Protocol for Metadata Harvesting (OAI-PMH).

The journal is indexed \& included in WorldCat Discovery Service (USA), CrossRef Metadata Search (USA), WorldCat (USA), OCLC (USA), Open J-Gate (India), EZB (Germany) Scilit (Switzerland), Airiti (China), Bielefeld Academic Search Engine (BASE) of Bielefeld University, Germany, PKP Index of Simon Fraser University, Canada. 


\begin{abstract}
The study examined the influence of gender and level of education on Posttraumatic Stress Reactions of Victims of Cattle Rustling conflict. The study was guided by two objectives. The first one was to find out whether gender influences Posttraumatic Stress Reactions. 384 victims comprising 258 males (67.2\%) and 126 females (32.8\%) were studied. Descriptive survey design was employed in the conduct of the study. The instruments used to collect data were students' demographic characteristics sheet and a 23-item Posttraumatic Stress Reaction Inventory DSM-5. T-test for independent samples and ANOVA were the statistical tools used to analyze data. Results revealed no significant influence of gender on Posttraumatic reactions of victims of cattle rustling in Zamfara state. In addition, lower level of literacy or its absence was found to elicit higher feelings of psychological reactions to traumatic events. Similarly, literacy level increases victims' coping strategies in dealing with traumatic experience. Part of the recommendations is the need prompt treatment of both men and women equally by teaching ways to manage their fears, and anxiety. There is the need for stakeholders in education especially the school psychologists to create enabling environment which will instill and sustain adult desire for education.
\end{abstract}

Key Words: Gender, Education and Post-traumatic Stress Reactions

\title{
Introduction
}

Cattle rustling is the act of forceful raiding of livestock from one community by another often leaving behind destruction of property and loss of lives (Cheserek, Omondi, \& Odenyo, 2012). The first recorded cattle rustling was said to have been conducted over seven thousand years ago (Rangers and Osborne, 2006 sited in Momale, 2015). Hence, it's not a new practice but only change dimension from theft to extreme violence. According to Okoli and Okpaleke (2014), the later dimension of cattle rustling in Nigeria takes the form of massive village raids whereby herding communities are attacked, mostly in retaliation for previous showdown by community vigilantes or collective resistance by community dwellers. In some societies, it has been associated with kidnapping of girls, rape and destruction of properties (Momale, 2015). Though, different opinion on the root cause of the transformation of cattle rustling has been raised by different scholars (Okoli and Okpaleke, 2014; Egwu, 2015; Momale, 2015). Jungle justice, reprisal attacks, deprivation, weak security system and proliferation of illegal weapons were however among the major reasons reported to have sparked the cattle rustling to its present state in Zamfara State, exposing the victims in persistent trauma that can led to Post-traumatic Stress Reactions, hence PTSD. PTSD is a severe anxiety disorder that can develop after exposure to any forms of traumatic events including Cattle Rustling.

The concept Post-Traumatic Stress Reaction can be best understood from the work of Mash and Wolfe (2005) who defined it as "persistent, frightening thoughts that occur after undergoing a frightening and traumatic event". Santrock, (2003) explained post-traumatic stress reaction as a disorder that developed through exposure to traumatic events such as war, severe oppressive situation, severe abuse and natural disaster. It is assumed that oppressive situations such as rustling, loss of loved ones, accident, interpersonal conflict or military combat could affect victim's entire life and can also lead to some forms of behavior disorders such as aggression that may eventually leads to militancy - creating various cycles of violence (Burke, 2006). Not all who are exposed to a traumatic event develop PTSD, indicating there may be vulnerability factors that contribute to the development of PTSD (Yehuda, 1999 cited in Frank, Zamorski, Lee, \& Colman, 2018). Gender and education level of victims are among these factors. Most notably, gender has been explored as a potential predictor of increased PTSD following combat exposure; however, findings have been mixed (Frank et al., 2018).

A lot of psychological theories have provided explanation to what constitute gender differences. The psychology literature is filled with consistent empirical findings indicating sex differences between male and female's personality (Krampen, Effertz, Jostock \& Muller; 1990). For instance, many empirical findings reported that girls or women show higher score in trait anxiety than boys and men which could give a signal on their reaction to traumatic events. Many gender studies have been conducted with regards to PTSD. Perkonigg, Kessler, Storz, and Wittchen (2000) have reported that women develop PTSD more often than men. In another comprehensive study on gender difference in PTSD (Ditlevsen \& Elklit; 2010), it was established that women were approximately twice as likely as men to develop PTSD during their lifetime. However, it has been reported that the increased prevalence of PTSD in women remains even when trauma type is controlled for. Indications have been made that different trauma types show variations in the extent of gender differences in PTSD prevalence and as such gender shows variation in its effect on PTSD according to trauma type. Gavranidon and Rosna (2003) also added (in their findings) that men experience traumatic events more than the women but posttraumatic reactions last longer in women than in men. Moreover, Frissa, Hatch, and Gazard (2013), believed that PTSD symptoms are very high among unemployed 
especially those who do not work because of some health challenges. Nasar, Zulqarnain, Inayat, \& Khan (2016) found Education as one of the significant predictors of post-traumatic stress reaction in their study. Traumatic events may render victims helpless by overwhelming force, disrupt a sense of control, connection and meaning, etc. (Almazar, 2007)

Based on the prevalence of cattle raids in Nigeria, Okoli and Okpaleke (2014) placed Zamfara State among the critical flashpoint of cattle rustling. Most affected Local Government in the state with a lot of causalities are Maru, Tsafe, Zurmi, Birnin Magaji and some part of Anka and Kauran Namoda (247ureports, 2014; Okoli and Okpaleke, 2014; Momale, 2015). Cases of extreme violence linked to cattle rustling in Zamfara have been reported (AllAfrica.com, 2013; IRIN, 2013; 247ureports, 2014; Cleen Foundation, 2014; and The Nation, 2016) where the affected individuals or communities were incessantly being exposed to trauma that could lead to a severe anxiety disorder (PTSD). The major concern of government and other humanitarian agencies mostly focuses on providing relief inform of material resources with little or no concern on the connectedness of cattle rustling and posttraumatic reactions of victims. The reactions cut across many strata such as male/female, young/aged, literate/illiterate etc. as evident from literature. It is based on this premises that the study is set out tofind out whether gender has any interaction on posttraumatic reactions among victims of cattle rustling, and also determine the influence of literacy/illiteracy on posttraumatic reactions among victims of cattle rustling in the study area.

\section{Method}

Participants were 384 victims of Cattle Rustling (258 males 67.2\% and 126 females 32.8\%) drawn from Eight (8) Local Government Areas of Zamfara State Nigeria (2017). The affected areas are Gusau, Anka, Bungudu, Birnin Magaji, Maradun, Maru, Shinkafi and Zurmi Local Government Area. This study used purposive sampling technique. This is a descriptive survey. Participants were reached through Zamfara State Emergency Management Agency and their District Heads. Participants were interviewed using structured questionnaire. The questionnaire consists of demographic variables (gender, literacy level, etc.) and 23-item Post-traumatic Stress Reaction Inventory DSM-5 (The American Psychiatric Association, 2013). The scale for victims was anonymous where participants were told the purpose of the study was to understand their wellbeing after the traumatic event(s). There was no treatment; they only reported their demographic characteristics and their feelings. According to literature PTSD has reliability of .91 while the index of Cronback alpha after a pilot test in Katsina revealed an index .81 . The index of .81 suggests that instrument is reliable. The research questions were analyzed using descriptive statistics, while the hypotheses were tested using t-test for independent samples and Analysis of Variance at $\mathrm{P}<0.05$ level of significance.

\section{Results}

The data collected were analyzed by Descriptive statistics, Analysis of Variance and Chi-square. The hypotheses tested are:

H01: There is no gender effect on Post-traumatic Reactions among Victims of Cattle Rustling in Zamfara State.

$\mathbf{H O}_{2}$ : There is no significant influence of literacy/illiteracy on Post-traumatic Reactions of Victims of Cattle Rustling in Zamfara state - Nigeria.

Table 1: Distribution of Respondents by Gender Type

\begin{tabular}{lll}
\hline Gender & Frequency & Percentage $\%$ \\
\hline Male & 258 & 67.2 \\
Female & 126 & 32.8 \\
Total & 384 & 100 \\
\hline
\end{tabular}

The table shows that a total of 258 representing $67.2 \%$ of the respondents are male victims and the rest 126 representing $32.8 \%$ are females.

Table 2: Distribution of Respondents by Educational Qualification

\begin{tabular}{lll}
\hline Educational Background & Frequency & Percentage $\%$ \\
\hline No Education & 235 & 61.2 \\
Primary & 71 & 18.5 \\
Secondary & 46 & 12.0 \\
Tertiary & 32 & 8.3 \\
Total & 384 & 100.0 \\
\hline
\end{tabular}


Table 2 gives highlight on the victims' educational qualification. It showed that 235 or $61.2 \%$ have no formal education while 71 or $18.5 \%$ acquired secondary education and the remaining 32 or $8.3 \%$ had their tertiary education.

Table 3: Mean and standard deviation of male and female on posttraumatic reactions among victims of cattle rustling

\begin{tabular}{|c|c|c|c|c|c|c|}
\hline Variable & & Gender & $\mathrm{N}$ & Mean & $\mathrm{SD}$ & Mean difference \\
\hline Post-traumatic & Stress & Male & 258 & 58.64 & 7.48 & \\
\hline Reactions & & Female & 126 & 58.26 & 5.86 & 0.38 \\
\hline
\end{tabular}

The result on the table 3 showed that, the mean difference of post-traumatic stress reactions for both male $(x=58.64)$ and female victims $(\mathrm{x}=58.26)$ was $(0.38)$. This shows that male and female victims have almost the same level of Post-Traumatic stress reaction. This result is further verified in hypothesis one (Table 4).

Table 4: Independent t-test Analysis on influence of gender on the post-traumatic stress reactions of victims

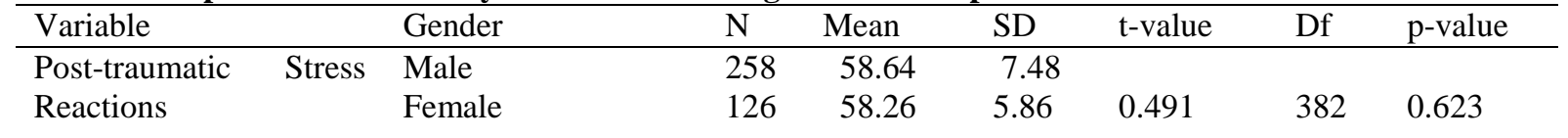

Calculated $\mathrm{p}<0.05$, calculated $\mathrm{t}>1.96$ at df 382

Results from table 3 showed that, there is no significant effect of gender on the post-traumatic stress reactions of victims. This is because the calculated p-value of 0.623 is higher than the 0.05 alpha level of significance and the compared $t$ value of 0.491 is lower than the $1.96 \mathrm{t}$ critical at df 382 . Therefore, the null hypothesis which state that there is no significant interaction or effect of gender on the post-traumatic stress reactions of victims, is hereby retained.

Table 5: Mean Distribution of Responses on the influence of Literacy on Post-traumatic Stress Reactions of Victims of Cattle Rustling in Zamfara State

\begin{tabular}{llll}
\hline Measure & $\mathrm{N}$ & Mean & SD \\
\hline No Education & 235 & 58.99 & 6.80 \\
Primary Education & 71 & 61.15 & 7.76 \\
Secondary Education & 46 & 58.63 & 7.34 \\
Tertiary & 32 & 55.70 & 3.46 \\
Total & 384 & 58.52 & 6.98 \\
\hline
\end{tabular}

The result from Table 5 showed that, victims' level of Education could determine level of post-traumatic reactions as it is seen in the mean scores. Here the No Education group $(x=58.99)$ as well as the Primary Educated $(x=61.15)$ seemed to be having more effect of the trauma. Although there was no intervention from the side of the researchers, the victims with tertiary education had the least reactions to the trauma of cattle rustling. This assertion is further verified in hypothesis two (Table $6 a$ and $6 b$ ).

Table 6a: Analysis of variance (ANOVA) statistic on the influence of literacy/illiteracy of victims of Posttraumatic Stress Reactions of victims

\begin{tabular}{|c|c|c|c|c|c|}
\hline & Sum of Squares & Df & Mean Square & $\mathrm{F}$ & Sig. \\
\hline Between Groups & 838.125 & 3 & 279.375 & 5.946 & .001 \\
\hline Within Groups & 17855.708 & 380 & 46.989 & & \\
\hline Total & 18693.833 & 383 & & & \\
\hline
\end{tabular}

The result on table 6 showed that, in the Analysis of Variances statistics, the calculated p-value of 0.001 is lower than the 0.05 alpha level of significance and the computed F value of 5.946 is higher than the $2.60 \mathrm{~F}$ critical value. Hence, the literacy/illiteracy significantly influenced post-traumatic reactions of victims of cattle rustling in Zamfara 
state. To further highlight the level of the influence of literacy/illiteracy on the victims, Scheffe's Post Hoc tests statistic was conducted on their Educational Qualifications (Table 6b).

Table 6b: Post Hoc Scheffe's means comparison statistics of Post-traumatic stress reactions on victims' literacy/illiteracy level

\begin{tabular}{llll}
\hline Educational Qualification & $\mathrm{N}$ & \multicolumn{2}{c}{ Subset for alpha $=0.05$} \\
& & 1 & 2 \\
\hline Tertiary & 32 & 55.7042 & \\
Secondary & 46 & 58.6304 & 58.9915 \\
No Education & 235 & & 61.1563 \\
Primary & 71 & .094 & .285 \\
Sig. & & & \\
\hline
\end{tabular}

Table $6 \mathrm{~b}$ examined the effect of each educational qualification by Post Hoc Scheffe's tests. The analysis showed that, the means of those who attained Tertiary and Secondary education were placed in least subset 1 while those of with No education and Primary education in subset 2 . This shows that the victims with no formal education had the highest post-traumatic stress reactions while those with high education had lower post-traumatic stress reactions. Therefore the null hypothesis which states that there is no significant influence of literacy/illiteracy on Posttraumatic Reactions of Victims of Cattle Rustling in Zamfara state, is hereby rejected.

\section{Discussion}

In this study, the results of findings did not establish any significant gender interaction in determining victims' posttraumatic stress reactions. This implies that male and female victims of cattle rustling in Zamfara state have the same level of posttraumatic reactions. In other words, no clear advantage of any particular gender over the other was established. This result agrees with the findings of Khattak \& Khattak (2014) and Nasar, Zulqarnain, Inayat, \& Khan (2016), where no gender differences were also found on posttraumatic stress reactions among flood victims of Nowshera and Lahore respectively. Also, Frank et al. (2018) found no gender differences. However, inconsistent results were established by Perkonigg, Kessler, Storz, \& Wittchen (2000) and Solomonm, Gelkopf \& Bleich (2005) who found a significant gender effect on posttraumatic reactions in their separate studies, where female victims reported higher reactions than their male counterpart. The reason for this variation in the result may be attributed to geographical, societal and cultural differences the study was carried out as well as nature of the conflict/violence that traumatized participants observed in each study.

Regarding the influence of literacy/literacy on victims' occupation, the results showed an existence of a significant influence. As was expected and found in previous research there was a significant influence of educational level on the economic activities of victims after the traumatic experience. This finding gives credence to Weissman et al. (2005) and Nasar et al. (2016) who found Education level as a significant predictors of post-traumatic stress reaction, but contradict that of Khattak \& Khattak (2014) whose results revealed no effects with respect to education level. Literally this result provides support that education is a breakthrough in all aspects of life because it has significant effect on the quest for economic recovery. The findings further suggest that education is an instrument to be used in addressing economic problems in Zamfara state and Nigeria at large.

\section{Conclusion}

The findings highlight the development of posttraumatic stress reactions after the conflict of Cattle Rustling. This suggests that the victims of Cattle rustling in Zamfara state have reported high symptoms of PTSD. Conflict triggers one's emotional wellbeing especially women. The influence of education on victims' reaction to trauma is not surprising - revealing how education shapes human behavior (both normal and abnormal). Thus, the present study suggests the need for promoting literacy across all categories of people in Zamfara state - Nigeria.

\section{Recommendations}

Based on the findings, it is recommended that there is the need for prompt treatment of both men and women equally by teaching ways to manage their fears, anxiety, etc. There is also the need for stakeholders in education especially the school psychologists to create enabling environment which will instill and sustain adult desire for 
education. Equally important is the need for victims of traumatic events to avoid trauma reminders through that the unwanted feelings will automatically disappear.

\section{Funding}

This research was funded by Tertiary Education Trust Fund (TETFund) under Institution Based Research (IBR) intervention.

\section{References}

[1]. 247ureports (2014). The Genesis of Zamfara Cattle Rustling and Quest for Community Dialogue. 247ureports online at http://247ureports.com/the-genesis-of-zamfara-cattle-rustling-and-quest-for-community-dialogue/ Retrieved September 11, 2016).

[2]. AllAfrica.com (2013). Nigeria: Bandit attacks displace northern herders. allafrica.com/stories/201306191213.html Retrieved September 12, 2016.

[3]. Almazar, R. (2007). Gender Differences in PTSD. Psychological Bulletin, raul@almazarconsulting.com.

[4]. Burke, S. (2006). Children and War: Circle of Violence in Psych. http://www.psychology.org.an/...tions/inspych/highlights2006. Retrieved on November 11, 2016.

[5]. Cheserek G.J, Omondi P, \& Odenyo V.A.O. (2012). Nature and Causes of Cattle Rustling among some Pastoral Communities in Kenya, Journal of Emerging Trends in Economics and Management Sciences, 3 (2): 173-179.

[6]. Cleen Foundation (2014). Election Security Threat Assessment: Towards 2015 Elections. 3rd Edition. http://cleenfoundation.html. Retrieved on September 15,2016.

[7]. Ditlevsen, D.N. and Elklit, A. (2010). The combined effect of gender and age on posttraumatic stress disorder: Do men and women show differences in the lifespan distribution of the disorder? Annals of General Psychiatry, 9, 32.

[8]. Egwu, S. (2015). The Political Economy of Rural Banditry in Contemporary Nigeria. In: Kuna, M. J. and Ibrahim J. (Ed) Rural Banditry and Conflicts in Northern Nigeria. Center for Democracy Development, Abuja, Nigeria, pp. 22.

[9]. Frank, C., Zamorski, M. A., Lee, J. E. C., \& Colman, I. (2018). Deployment-related trauma and post-traumatic stress disorder: does gender matter? European Journal of Psychotraumatology, 9(1).

[10]. Frissa, S., Hatch, L. S. \& Gazard, B (2013). Trauma and current symptoms of PTSD in a South East London community. Berlin:Springer.

[11]. Gavranidon, M. \& Rosna, R. (2003). The Weaker Sex? Gender and post-traumatic stress disorder. Anxiety and Depression, 17(3):130-139.

[12]. IRIN (2013). Bandit attacks displace northern Nigerian herders. http://www.irinew.org/fr/report/98251/bandit-attacksdispalce-northern-Nigeria-herders. Retrieved on September 14, 2016.

[13]. Khattak, S. R., \& Khattak, S. U. (2014). Prevalence of Post-Traumatic Stress Disorder in Flood Affected Population of Banda Sheikh Ismail, District Nowshera. Journal of Postgraduate Medical Institute (Peshawar-Pakistan), 28(1).

[14]. Krampen, G., Effertz, B., Jostock, U. \& Muller, B. (1990) Gender differences in personality: Biological and/or psychological? European Journal of Personality, 4, 303-317.

[15]. Mash, E. J. \& Wolfe, D. A. (2005) Abnormal Psychology: 6th Edition. Toronto.

[16]. Momale, S. B. (2015). Changing Methods of Animal Husbandry, Cattle Rustling and Rural Banditry in Nigeria. In: Kuna, M. J. and Ibrahim J. (Ed) Rural Banditry and Conflicts in Northern Nigeria. Center for Democracy Development, Abuja, Nigeria, 69-109.

[17]. Nasar A., Zulqarnain S., Inayat A., \& Khan M.N.S. (2016). Stress reaction and Post-traumatic stress disorder among flood victims of Lahore- Pakistan and role of community (ROC). The International Journal of Psychosocial Rehabilitation, 20(2): 75-84.

[18]. Okoli A. C. \& Okpaleke F. N. (2014). Cattle Rustling and Dialectics of Security in Northern. International Journal of Liberal Arts and Social Science, 2(3): 109-117.

[19]. Perkonigg A., Kessler R. C., Storz S., Wittchen H. U. (2000). Traumatic events and posttraumatic stress disorder in the community: prevalence, risk factors and comorbidity. Acta Psychiatr Scand, 101:46-59.

[20]. Santrock, W. (2003). Educational Psychology (3rd ed), New York: Mcgraw Hill Companies Inc.

[21]. Solomonm, Z., Gelkopf, M., \& Bleich, A. (2005). Is terror gender-blind? Gender differences in reaction to terror events. Social Psychiatry and Psychiatric Epidemiology, 40:947-954.

[22]. The Nation (2016) Ending cattle rustling. The Nation online newspaper at http://thenationonlineng.net/ending-cattlerustling/. Retrieved on September 11, 2016.

[23]. Weissman, M. M., Neria, Y., Das, A., Feder, A., Blanco, C., Lantigua, R., ... Olfson, M. (2005). Gender Differences in Posttraumatic Stress Disorder Among Primary Care Patients After the World Trade Center Attack of September 11, 2001. Gender Medicine, 2(2), 76-87. 